\title{
ELIMINATION OF GENDER DISCRIMINATORY LEGAL PROVISION BY THE SUPREME COURT OF NEPAL WITH REFERENCE TO WOMEN'S RIGHT TO PROPERTY
}

\author{
Nutan Chandra Subedi*
}

\section{INTRODUCTION}

Women's rights are part of human rights and gender justice is integral to social justice. Definitely, women are inevitable complement of human society and it can not be imagined of a society without the existence of women. So, it is not exaggerated to say that the violation of women's right is deemed to be the violation of the rights of entire human society. The property right is the subject of economic justice that is needed to every human being in order to subsist as a human person in society.

Indeed, women's right to property was the most and intensively discussed issue in various workshops and seminars at local and central level, after the promulgation of the Constitution of Kingdom of Nepal, 1990, which ensured to eliminate discriminatory legal provisions through the initiation of judiciary. Basically, where two women activist lawyers challenged the discriminatory legal provisions outlined in the chapter on Partition Share of National Code, 2020, before the Supreme Court, it was shaped extensively as hot issue of discussion throughout the nation. While the court issued a directive to introduce appropriate bill, it opened the gateway of spate in respect of negative and positive impacts in this respect. Consequently, after the dozen of attempts made by feminist spirited parliamentarians and women rights activities, $11^{\text {th }}$ amendment in National Code, 2020 regarding women rights Bill was passed in $21^{\text {st }}$ session of parliament in September 25, A.D. This major break had heralded the genesis of new dimensions of reformation in women's property laws through the elimination of discriminatory laws in existing Nepalese law. This study basically endeavors to focus the rectification of gender discriminatory women's property laws through the Supreme Court of Nepal. It is also strived to give concept of women's property right in international, governmental and legislative initiation.

\section{CONCEPT OR WOMEN'S PROPERTY RIGHT}

Hence, it is endeavored to clarify the meaning and concept of women's property right, Blackstone's concept in the course of his comprehensive commentary on the common law set forth the fiction that informed and guided the treatment of married women in the English law courts, is relevant to explain. He opined that when a woman gets married, her legal identity is merged into that of her husband and she is civilly dead. She could not sue, be sued, enter into contracts, make wills keep her own earning, control her own property. Hence, 


\section{ELIMINATION OF GENDER DISCRIMINATORY...}

Blackstone is not seen to be liberal towards the independent right of property for women. In fact, the position of women in a particular society is the test of a nation's culture. In ancient time, the wife was subject to her husband. Among Greeks one of the most cultured races of the ancient world the women had no position. In Pre-Christian era, the days of Roman Empire women had freed themselves from the Patria Potestas' of her father and had successfully acquired rights to possess property and claim divorce. But gradually with the advent of Christianity, it deprived women of their freedom. St. Paul, one of the early church's fathers had stated that man was made for god, but women for men. In this way the advent of Christianity women were deprived from property right in western society.

In the old Arabian society, there was no limit to the number of wives and the Arab's major concerns were wine, women and war. The Quoran refers that the share of female heir is half of that of male hair. The Quronian law recognizes a daughter's right to inherit the property of the father. The daughter, if she is single, takes half share but if sisters are two or more their share is two thirds of the estate. If the deceased has left a son, he inherits the whole property but if on the other hand, he has left a daughter she takes half the property and the other half may be taken by a distant male agnate. The childless widow takes no share in her husband's lands but she entitled one fourth share in the value of buildings and movable property. Thus the Quoranic law discriminates between son and daughter.

So far as the Hindu jurisprudential concept of women's property right is concerned, the Vadic period (2500 BC to $1500 \mathrm{BC}$ ) is discovered to be more favorable age regarding the women's rights issue including their property rights. The religious sacrament made the wife and husband as the couple, joint owners of the household. In $4^{\text {th }}$ Rig-Veda the husband and wife are described as taking equal parts in sacrificial rites. Men and women had equal statue in the social rights and they had equal share in responsibilities and duties. The concept of Stridhan (Women's exclusive property) is as old as the Rig-Veda seems to have recognized the following items of property as constituting a women's Stridhan: gifts from parents and brothers, gifts before nuptial fire, gifts in the bride procession and earning by mechanical arts. These Vadic verdicts about Stirdhan definitely ensilage the honourable position of women. By the period of Upanishad and Smritis (1500 BS to $500 \mathrm{BC}$ ) it degraded the honour of women in terms of the issue of women's right to property. It is stated in Manusmriti that 'a wife, a son, and slave, these three are traditionally said to have no property; whatever property they acquire belongs to the man to whom they belong. Similarly, 'a woman should not make a great hoard of the family property that belongs to several people, not even her own valuables, without her husband's permission. These two verdicts of Manusmriti are more regressive against women's property: 'And the brothers should individually give their virgin (sisters) some thing form their own portions, a quarter share of each one's own portions.' If they did not give this, they would fall. As such, 'a son is just like one's self, and a daughter is equal to a son. How can someone else takes (the fathers') property when she stands for his self. These responses to some extent are seemed justified on the side of women, but their individual autonomy is not accepted under the verdict of Manusmriti. 
As regards the concept of women's property right issue the great Marxist philosopher F. Engels states that the dependency of economic resources on man, deprives the right to property of women. Such bitter circumstance is being flourished by patriarchal structure of society. Men's control over private property, and the ability thereby to generate a surplus, changed the family form to a patriarchal form where women, and often slaves, became the property of the father and husband. Engels, thus, affirms that the commencement of patriarchal family structure heralded the deprivation of property of men, and that was great defeat of female sex. In this way western and eastern religious values and norms were entrenched in legal system of both society that had hardly secured women's right over the ownership of property. So all religious dogmas that prefer male superiority and female inferiority, are responsible for discriminatory approaches of legal system against women's dignity in every society.

\section{PROBLEM OF DISCRIMINATORY LEGAL PROVISIONS AGAINST WOMEN'S PROPERTY RIGHTS}

\section{Discriminatory WoMen's Property LAWS Before $11^{\mathrm{TH}}$ AMENDMENT OF NATIONAL CODE, 2020}

Before 11th amendment of National Code 2020, the said new Muluki Ain 2020 did not bring any progressive reformation in the field of women's property right. This said new Muluki Ain was seemed to be more regressive than previous Muluki Ain (National Code), 1910, because the previous code had the provisions of equal share of property as like brothers after attaining the age of 35 years. But under this new National Code, 2020 the daughter who is attaining the 35 years of age, was entitled only half of share of property while her brother could get full share o property. However, after the first women's conference of International women Year 1975 A.D. it amended this new National Code 2020, in which it was eliminated the system of half share of property for the daughter, and she was entitled equal share of property as like her brother if she is unmarried and attains the age of 35 years. Nevertheless such amendment was inadequate for the total elimination of gender discriminatory laws, and Nepalese women were prejudiced from following major features of discriminatory legal provisions of National Code, 2020, before $11^{\text {th }}$ amendment of this code.

\section{DAUGHTER WAS DENIED AS COPARCENER}

The son was by birth recognized as coparcener of the ancestral property while, in order to be eligible as coparcencer a daughter had to complete 35 years of age and should remain unmarried.

\section{Property Vs Sexuality for Daughter}

A daughter was not eligible for ancestral property if she gets married or makes elopement even after 35 years of age. In other words, after obtaining partition, if a daughter above the age of 35 years gets married or eloped, partitioned property would be passed on the heirs after deducting the marriage expenses whereas a son under the similar circumstance would not lose his right over partition share. 


\section{ELIMINATION OF GENDER DISCRIMINATORY...}

\section{SILENCE ABOUT THE MAINTENANCE OF UNMARRIED DAUGHTER}

It was disregarded about the maintenance of unmarried daughter. The law didn't make ay concern of maintenance mandatory for fathers to their daughters by providing food and shelter. In other words, parents weren't bound to be responsible for providing maintenance, education shelter and other expenses except marriage expenses to daughters. On the other hand the father was bound to provide all the facilities as mentioned above to his son, otherwise such father had to provide him partition. But in similar manner, a daughter under the age of 35 years of age could not claim for partition.

DisCRIMINATORY ATTITUDE OF SUCCESSION ON INTESTATE OR INHERITANCE PROPERTY

It was provided the right to inheritance to the daughter only after her brother. In other words, the heir of inheritance right was the nearest coparcener of male descendent with seven generations. As long as there was existence of male descendent of their own family, other heirs were not regarded as the nearest once. Thus, this provision had recognized only male ancestors as the heirs for inheriting property. Neither the daughter nor her off-springs were recognized as heirs.

\section{Discriminatory Legal Provisions Concerning Women's Right to} Property AFTER THE $11^{\text {TH }}$ AMENDMENT OF NATIONAL CODE, 2020

There are various discriminatory legal provisions against women's property right issue even after the $11^{\text {th }}$ amendment of National Code, 2020 B.S.

\section{Discriminatory Provisions of Chapter on Partition Share}

As regards the ancestral property rights of women, the law makers did not seem to be liberal to provide this right to the daughter as to the son. The daughters are provided however, the right to ancestral property by one hand but after the marriage this ancestral property is to be returned to her father's family other hand snatches such right. In these circumstances most propagated victory of daughter's over paternal right to property is seemed to be meaningless. It seems that women's entitlement over ancestral property, even after the $11^{\text {th }}$ amendment of the National Code, 2020 is more illusory than real.

\section{Discriminatory Provisions of InTESTAte Property}

The major defective as well as discriminatory aspect against women's right even after $11^{\text {th }}$ amendment is the continuation of section 12(a) of the chapter on Intestate property of National Code, 2020, where it is enunciated that if unmarried daughter gets marriage she is supposed to return remaining property to her maternal family. Indeed this provision is not only discriminatory between son and daughter but also between daughter and daughter on the basis of marital status, whereas the man who has acquired the intestate property, has no any liability to return such property to any other family. The obligation laid upon the daughter to return the intestate property is definitely the gender discrimination against daughter on the basis of sexual as well as marital status. 


\section{WOMEN's EXCLUSIVE PROPERTY}

Particularly, section 2 and 7 of the chapter on Stri Amsa Dhan of National Code, 2020 are seemed to be discriminated against the right to self-determination for enjoying property. The provision of section 2 obliges the women to take consent of her family members even if she is separated from the her family. Regardless, the 11th amendment of National Code could not eradicate such provision. Likewise, section 7 of the this chapter also discriminates against right to self- determination/consideration towards the enjoyment of her property. Essentially, this section constrains the women to select the property or her sexuality. The provision intends to control her sexuality under the structure of patriarchal society.

\section{Discriminatory Provision UNDER LAND ACT 2021}

The land Act, 2021, previously provided the tenancy right that was transferable only to wife, husband or sons who is trusted by the landlord among the family member of tenant. Daughter was not included in this respect. After the new amendment of land Act 2021, in 2053, two members have been included for acquiring of tenancy rights, they were daughter-in -law and daughter who is unmarried and has attained the age of 35 years. It has not only been discriminated concerning the transformation of tenancy rights between men and women, but also discriminated between woman (daughter-in-law) and woman (daughter who should be unmarried and attained 35 years of age). Indeed, in Nepal there is $60.5 \%$ contribution of women in agricultural product while there is $39.5 \%$ of men in total agricultural production. But the ownership of man is $89.17 \%$ over the land and $10.83 \%$ is of women. As like the suppression of landlord is existed in community and suppression of men is in family, that has been reasoned to be occupied of the land. In fact the issue of land rights of women is attached with the whole empowerment of women.

Recent Change of Women's Property LaWs Through The Gender EQUALITy RELATING TO SOME ACT (AMENDMENT), 2063 (HEREIN AFTER IT SHALl BE CALLED G. E. ACT, 2063)

In a changing situation after people's movement-II of 2062/63 B.S. it has taken into account concerning the issue of elimination of gender discriminatory legal provision in existing Nepalese legal system. It has been eliminated many of the gender discriminatory legal provisions in women's rights issue including women's property right through this Act, 2063. The G.E. Act 2063 has abrogated many of the discriminatory legal provision concerning of National Code, 2020. Basically, G.E. Act, 2063 has rectified almost the discriminatory legal provisions regarding - partition share of property, women's exclusive property, chapter on intestate property and land Act 2021 in which it was embraced the spirit of human rights and gender justice. 
NATIONAL AND INTERNATIONAL COMMITMENT TO ELIMINATE THE DISCRIMINATORY LEGAL PROVISIONS AGAINST WOMEN'S PROPERTY RIGHT

\section{NATIONAL COMMITMENT THROUGH GOVERNMENTAL INITIATIVES REGARDING THE ELIMINATION OF GENDER DISCRIMINATORY LAWS}

'National policy must be read by the court as supporting women's claims to equal treatment even where customary law has traditionally been 28 (a) applied. Under the governmental initiation regarding elimination of gender discrimination the Nepalese Government has adopted various programmes and policies through National plan and plan of actions. The history of planning wise governmental initiation concerning the advancement of women and elimination of gender discrimination is no longer than two decades. The sixth five year plan (1980/81-1984/85) is the first plan that attempted to increase employment for women and to carry out the goal to reform laws and regulations, which inhibit women's participation in development. So, many of the international legal instruments including CEDAW-1979 were remained to be ratified by the nation.

The $7^{\text {th }}$ Plan (1985/86-1990/91) expanded the activities mentioned in $6^{\text {th }}$ plan. Under this plan it was expected that legal reform would be affected to remove provisions hindering women's participation in National development. Indeed, this plan also had no any formidable change to promote the eradication of discriminatory laws for the empowering as well as mainstreaming the women in national development. The $8^{\text {th }}$ plan (1992/93-1996/97) was more important because of the formidable change of political system. It was the initial period of multi party democratic system. After the formulation of constitution of kingdom of Nepal, 1990 and formation of first elected government various international instruments of Human rights conventions including Convention on the Elimination of All forms of Discrimination against women (CEDAW-1979 were rapidly ratified by the then democratic government. Besides, there were emerged various non-governmental organizations (NGOs) and international nongovernmental organizations (INGOs) which had effectively contributed for campaigning the elimination of gender discriminatory laws.

The major outcome of Ninth Plan (1997-2002) was the $11^{\text {th }}$ amendment of National Code, 2020 with an effort to abolish the various discriminatory laws against women. The amendment was positive in respect of women's right to property, abortion, sexual exploitation, minimum age of marriage and marriage and divorce. The other major achievement in the direction of elimination of discriminatory laws was the formation of the High level committee had submitted its report recommending the elimination of various discriminatory laws. The major objective of Tenth Plan (2002-2007) was to create egalitarian society based women's rights by improving GDI (Gender Development Index) and by abolishing all sorts of discriminations against women for the realization for economic growth and poverty eradication. The policy and work strategy of tenth plan was legal reforms concerning women's issue which was said that 'necessary steps to be taken to formulate new laws and amend the existing ones on the basis of gender equity, while devising special arrangement for transition period. 
And, recently the Nepal government has put forward the Three Years Interim Plan (2007/08-2010/11) in which it has expressed the commitment to ensure $33 \%$ of women's representation in state mechanism. Also it has emphasized to eliminate all gender discriminatory provision of existing laws. It has been insisted to embrace the value and norms of human rights and gender justice in order to advance the women empowerment, and to make autonomous National women commission.

National plan of Action on gender equality and women empowerment2004 A.D. is other powerful commitment of governmental initiation for improving women empowerment under which three major concerns have been focused i.e. (1) women and poverty, (2) women and economy, and (3) women and human rights. Basically, women and Human Rights have been emphasized: to ensure women's human rights according to CEDAW and Beijing Declaration, to end the exploitation of women and protection of human rights, to incorporate new laws in order to end exploitation against women, to review the discriminatory provisions of existing laws and to make arrangement for new laws with view to women's human rights. Similarly, National plan of Action for implementing the Convention on the Elimination of all forms of Discrimination Against Women (CEDAW) Jan. 1. 2004 is other governmental initiation regarding the elimination of gender discrimination. This plan of Action has been framed to implement women's human rights and other provisions outlined in CEDAW successfully and effectively. This plan of Action mainly focuses for amend the legal provisions which are discriminatory against women and enact new laws in line with the convention when deemed necessary by studying and reviewing the prevailing laws. Thus, above mentioned governmental initiations through its plans, plan of actions and policies give emphasis for elimination of existing discriminatory legal provision and to advance the empowerment of women.

\section{INTERNATIONAL LEGAL COMMITMENT TO ELIMINATE THE DISCRIMINATORY Legal Provisions Against the Issue of Women's Right to Property}

There is no separate international legal instrument regarding the property right, but international human rights conventions or instruments have ensured the property rights for both men and women. State parties are morally obliged to apply the human rights in their domestic laws as being the signatory state of such international instruments.

The Universal Declaration of Human Rights (UDHR) 1948 is one of the first international legal frameworks regarding human right that was adopted by UN General Assembly in December 10, 1948. This declaration is the beginning point of the modern human rights jurisprudence and an international measure or direction for every democratic state. Article 2 of the UDHR states that everyone is equally entitled to all rights and freedom set forth in this declaration without distinctions being made on grounds of their sex, etc. This Article guarantees all rights including property rights also, and without any distinction women also are entitled to enjoy this right. No one shall be arbitrarily deprived of his/her property. This provision of UDHR is the inevitable basis for the attempt of elimination of discriminatory legal provision for all signatory states. 


\section{ELIMINATION OF GENDER DISCRIMINATORY...}

International covenant on civil and political rights (ICCPR) 1966 and International Covenant on Economic, Social and Cultural Rights (ICESCR)-1966 are the prime international human right instruments that have established as formal convention of human rights for all men and women equally. An ideal society requires an environment where each human individual can exercise his/her freedoms without fear and want. Property is a means of human prosperity and thus is directly related to the development of the person. Both men and women, having their inherent dignity protected by international human right law, enjoy equal rights to own, possess and dispose their property. Article 26 of the ICCPR-1966 states that 'all persons are equal before the law and are entitled without any discrimination and guarantees against discrimination on the basis of sex, and no law can be held justifiable which directly or indirectly deprives the women from the ownership of property.

As such ICESCR-1966 guarantees the equal rights of men and women to the enjoyment of all economic, social and cultural rights set froth in present covenant. This covenant obliges the state party to ensure equal justice concerning economic, social and cultural rights without any discrimination including sex. A person, thus, either man or woman can achieve the meaningful dignity, self determination and inheritance rights if there is no discrimination of economic, social and cultural rights.

One of the historical breakthrough in the sphere of women's human rights, is the emergence of Convention on the Elimination of all kinds of Discrimination Against Women (CEDAW)-1979. The CEDAW convention defines them term "discrimination against women" shall mean any distinction exclusion or restriction made on the basis of sex which has the effect or purpose of impairing or nullifying the recognition, enjoyment or exercise by women, irrespective of their marital status, on a basis of equality of men and women, of human right and fundamental freedom in the political, economic, social, cultural, civil or any other field. The convention seeks to address pervasive social, cultural and economic discrimination against women, in which states are obliged to modify social and cultural patterns of condition that stereotype either sex or put women in an inferior position.

Articles 2 and 3 of CEDAW place an obligation on state parties that are signatories to the convention to eliminate discrimination and ensure equality. Women of signatory states should be enabled to exercise their rights, including the right of property, through appropriate constitutional and legal provisions. 'Women should be accorded equality with men before the law, with identical legal capacity in civil matters and the same opportunities to exercise that capacity. In particular, women should be given the equal rights to conclude contracts and administer property. It also states that both spouses should have same right to ownership, acquisition, management, administration enjoyment and disposal of property.

Committee on the Elimination of Discrimination Against women, has been established under Article 17 of the CEDAW convention. The adoption of the optional protocol of CEDAW- by UN General Assembly, has expanded the 
jurisdiction of the committee. Presently, the committee can entertain complaints under the optional protocol too.

Basically, the committee considered the initial report of Nepal at its $434^{\text {th }}$ and $439^{\text {th }}$ meetings, on 15 and 18 June 1999. The committee's comment observes that the committee is concerned that the government has not taken sufficient action to reflect the provisions of the convention in domestic laws, or to amend prevailing discriminatory laws. The committee is also concerned about the interpretation of discriminatory laws by the Supreme Court and the court's view that if any lands do not conform with culture and tradition, society will be disrupted. Similarly the committee recommends that a definition of discrimination in compliance with Article 1 of the convention be included in the relevant laws. The committee also urges the government to amend, as a matter of property, discriminatory laws on property and inheritance, the laws on marriage, nationally and birth registration, the Bonus Act and discriminatory criminal laws including new law on abortion. Thus, all above-mentioned international instruments emphasize to eliminate any kinds of gender discriminatory laws in various rights including property right of women.

\section{ROLE OF SUPREME COURT REGARDING THE ELIMINATION OF DISCRIMINATORY LEGAL PROVISIONS AGAINST THE WOMEN'S PROPERTY RIGHT}

Nepalese Supreme Court has played an important role regarding the elimination of gender discriminatory laws against women's rights. Basically after the promulgation of Constitution of Kingdom of Nepal, 1990, various international human rights instruments have been ratified by the first elected Nepalese government. Accordingly Nepal Treaty Act, was enacted in 1990 that has emphasized to give preference to the provision of international human rights instruments in case of a contradiction that are rectified by the state with the domestic laws. In this way the application of international human rights provision is being institutionalized through the decision of apex judicial body which is major component of state mechanism.

The Supreme Court is empowered to test the constitutionality of any legal provision that is inconsistent with the provision of Constitution of Kingdom of Nepal, 1990 under Article 88 (1). In this connection any Nepalese citizen can pursue for filing a writ petition before the Supreme Court on the ground of violation of his fundamental rights. Before the promulgation of this constitution the role of the court was not so strong.

Undoubtedly, after the promulgation of constitution of kingdom of Nepal, 1990 it has begun to set up the new genesis on the elimination of discriminatory legal provision against women's rights, including property right.

One of the famous cases in this concern is Meera Dhungana and Meera Khanal Vs HMG Ministry of Law, Justice and Parliamentary Affairs which is one of the historical breakthrough that commenced the point of legislative reform towards gender equality of women's right to property. However, the court's decision of this case was not so positive in this regard, yet the court's directive 


\section{ELIMINATION OF GENDER DISCRIMINATORY...}

order opened the gate way of the genesis of legislative reform concerning gender justice. The petitioners has mainly in this case challenged the constitutionally of section 1 and 16 of the chapter on partition share (Angshabanda) of National Code (Muliki Ain) 2020 which discriminates against the women's equal property right. The petitioner filed writ petitions under Article 2388 (1) of the Constitution of Kingdom of Nepal, 1990 challenging even though Article 1(1) of this constitution provides that all laws inconsistent with the constitution shall ipso facto be void in tune of Article 131, but the inconsistent laws are in existence till the date in their previous form on account of the respondent's lukewarm response to Article 131 of the constitution in this.

The petitioners have claimed that the impugned section 1 and 16 of the partition share (Angshabanda) are inconsistent with Article 11(2) of the Constitution of Kingdom of Nepal, 1990, Article 2 of UDHR-1948, Article 26 of ICCPR-1966, Article 3 of ICESCR-1966, and Articles 1, 15 and 16 of CEDAW1979. The petitioners therefore, requested the Supreme Court to declare void and ultra-vires the impugned legal provisions.

But the Supreme Court has categorically stated that declaring section 16 of the chapter on partition ultra-vires and providing daughter equal share of the property was not the solution to the problem. In this judgment, it is very unfortunate that the court could not see the prima facie discrimination in section 16. The court in fact escaped its obligation under Article 1, 11, 23, 88 and 131 by issuing a directive order to the government to present a bill in the legislature reviewing the law relating to property rights within a year from the date of the decision. The judgment also stressed the point that the society may not digest so many sudden changes in the prevailing social practices, modes and values, and directed the government for enactment of just provisions having due regard to the constitutional provisions of equality. Alternatively, the court feared that the son would be entitled only to the father's property and hence the situation then would be discriminatory against interest of the son.

Nevertheless, after the decision of this case as the issue of directive order in the name of government for introducing appropriate bill of regarding women's right to property initiated the public debate in order to eliminate discriminatory legal provision. Also, many of the human rights and women activities commenced the operation of campaigning to press the government for introducing appropriate bill before the parliament. It was nation wide vibration of the women's rights movement for the elimination of all discriminatory laws of existing Nepalese legal system. So the verdicts of court are against the spirit of women's rights but the directive order made the genesis point to begin the true movement of women's rights.

In the context of sacred mission of the elimination of discriminatory laws, many of the women right activists have been playing active role through the instrument of public interest litigation. In this connection Dr. Chandra Bajracharya Vs HMG/Secretariat of the Parliament, the petitioner has challenged some discriminatory laws of property law and other discriminatory issues under the National Code, 2020. Particularly, regarding the property laws the petitioner 
challenged the section 12 of the Chapter on partition share and section 2 of the chapter on Intestate property (Aputali) that are inconsistent with the right to equality under Article 11 of the Constitution of Kingdom of Nepal, 1990 and contrary with ICCPR, 1966 and CEDAW, 1979. These major instruments and incorporation of Nepal Treaty Act, 1990 the provisions of conventions are as equally enforceable as domestic laws. The petitioner further insisted that a long period has been elapsed after the commencement of the constitution but above mentioned impugned laws that are still discriminatory. So the petitioner requested before the court to declare void and ultra-vires to that extent of inconsistency with the constitution and above said international instruments of human rights.

In this case the court has revealed an attachment of religious based culture and tradition, preference of biological destiny for social unrest concerning legal change. As regards the attachment of religious based culture and tradition the court espouses a kind of rigidity in existing discriminatory law for the perpetuation of dogmatic norms and values. The court observes that 'law is a rigid and it should be made lively by its interpretation. The things to be observed are social structure, culture and tradition of country. Culture is practical, innovative welfare activities determined by discussion of foresighted thought of learned ancestors and filtered by time period. Tradition is the life style or functional method followed by society from time immemorial ... It can not be denied that there is great influence of Hindu jurisprudence in our legal system. Article 5 of the Constitution of Kingdom of Nepal, 1990 has declared Nepal as Hindu kingdom and ... we the follower of religion as handed down from ancient times having due regard to traditional practices, are Hindus." Hence the court explicitly disagree with the demand of petitioner regarding the issue of elimination of traditional gender discriminatory laws concerning property right.

So far the preference of biological destiny of women the court has made the basis of biological and natural differences. The court observes: "... it is undeniable fact that there is slight different position of men and women in society by nature of sexual differences. It is universally accepted principle that there is very less chance of absolute equality." Hence the court itself has created the ground of discrimination on the basis of biological difference. So Rajnis Osho rightly says 'men and women are naturally difference but they are not unequal. The issue of differences and inequality is not the same thing, the social inequality is man made issue, it has been made on the basis of biological difference which is against human right and justice.

As regards the concern of anxiety for social unrest the court views to maintain the legislative conservatism in the fear of social unrest in the patriarchal society if it happens the legal changes. The court opines: "constitution and laws are assumed on the basis of culture, tradition, ideology, belief and values. It is very important to not what would be the consequence of there is any change that is inconsistent with our culture and tradition. Such as situation may disturb whole social set up and structure and there is greater possibility, of creating social unrest in the society. Hence the court has disregarded the grounded fact that our cultural and traditional practices are guided by patriarchal values and norms where there 


\section{ELIMINATION OF GENDER DISCRIMINATORY...}

is dominant role of male supremacy and it has denied to share the power of women in state mechanism.

Nonetheless, the court has issued the directive order in the name of government to present appropriate bill before the legislative body, and it may be said that such directive order in respect of reforming defective legal provision is an aspect of positive response of the court.

In Sapana Pradhan Malla and Prakashmani Sharma for Pro-public Vs HMG/Ministry of Law, Justice and Parliamentary Affairs the petitioners had challenged section 26(1) of Land Act, 2021 B.S. (1964), according to which the tenancy right after the death of tenant is transferable to the wife or sons of the deceased tenant, whoever is trusted by the landlord. This provision denies the tenancy rights of daughter, married woman and widowed daughter in law and hence it violates the right to equality guaranteed under the constitution.

In this case, the Supreme Court decided that there was no sufficient cause and situation to declare section 26(1) of land Act, 2021 B.S. (1964) as ultra-vires to Article 11 of the constitution. The special Bench of the Supreme Court interpreted the forgoing provision as non-discriminatory on the following grounds: 'The tenancy right does not devolve to any one other than the family after the death of a tenant. Since a daughter goes to her husband's house after her marriage, the policy does not discriminate against her. The devolution of the tenancy rights to a daughter may have adverse impact on the interest of the land owner. Ultimately, the court in this case also, issued a directive order in the name of government to introduce an appropriate bill at parliament. So in this case the court has maintained double standard verdict. On the one hand, the court has denied the demand of petitioner on the other hand it has issued directive order to introduce an appropriate bill in this regard.

In Prakashmanai Sharma and others Vs. HMG/Office of Prime Minister and Council of Minister the petitioners had challenged the sections 1 (a) and 16 of the Chapter on partition share of National Code, 2020. According to petitioners such impugned sections are inconsistent with the spirit of Article 1(1), 11(4), 2(2) and (3), 17(1) of the Constitution of Kingdom of Nepal, 1990, Article 1, 2, 7, 16 and 17 of UDHR, 1948, Article 3 and 16 of ICCPR- 1966, Article 1, 2, 3, 4, 5, 6, 15 and 16 of CEDAW-1979; and 9(1) of Nepal Treaty Act, 1990. The petitioners therefore have asked before the apex court to declare null and void the impugned discriminatory laws under Article 88(1) of the Constitution of Kingdom of Nepal, 1990.

In this case the court has demonstrated the positive responses on property right of women from the ancestral property after getting marriage. The court observes: 'Section 1 of the chapter on partition gives equal right to daughter to get one share and once she gets the share of property she has full right to enjoy, use, sell or dispose the property, it also compels the daughter to return the remaining property once she gets marriage ... Due to this impugned provision the goal of $11^{\text {th }}$ amendment of National Code to provide equal partition right to daughter has been vitiated and it ultimately results in discrimination as defined in the Article 1 of the CEDAW convention. 
In spite of delivering the above mentioned positive responses, the court is seemed to be reluctant for declaring null and void the discriminatory legal provision. The court held: 'It is yet to study the scope of the implementation of gender justice and its effect in change legal system regarding ancestral property of married daughter. It is the subject of legislative policy under the jurisdiction of legislature and it is not subject of usurpation of judicial function. So, it could not be agreed with the petitioner's demand to the extent that these provisions are inconsistent with Article 11 of the constitution for declaring null and void under Article 88(1). As like preceding writ petition concerning public interest issue for eliminating discriminatory legal provisions in this case the court has issued directive order in the name of government for introducing appropriate bill before the parliament.

In the context of mission of elimination of discriminatory laws of property of women, the women right activists have not yet given up even after 11th amendment of National Code, 2020. In Lily Thapa Vs Office of Prime Minister and Council of Ministers the petitioner has challenged section 2 of the chapter on women's Exclusive property of the National Code, 2020 in which it is claimed that this impugned section 2 is inconsistent with the Article 11(1), and 17 of the constitution. Article 26 of ICCPR, 1966, Article 2 and 3 of ICESCR- 1966 and Article 1, 2, 3 and 15 of CEDAW-1979. So the petioner has requested before the Supreme Court to declare ultra-vires of this controversial provision under Article 88(1) of the Constitution of Kingdom of Nepal.

The court has not only emphasized the substantive justice but also insisted the actual application of the women's property right under the value of procedural justice. The court observes: the impugned provision of chapter on women's exclusive property, has restrained the promotion of gender justice. It is discerned to have adverse effect over the right to property and ownership. There is no reasonable concept of property right if it is restricted to enjoy one's own property with one's willingness. Furthermore, the court held that there is no restriction to use immovable property for man on the ground of their marital, unmarried, or widower status, but alternatively women face restriction to use their immovable property on the ground of their marital status. This provision imposes unreasonable restriction to women and it is against gender as well as universal value of justice. Hence the count has signified the importance of result of actual enforcement of property right of women in which they can feel of actual spirit of gender justice.

So, the court has displayed its agreement with the demand of petitioner as stating: 'The impugned section 2 of the chapter or women's exclusive property of National Code, 2020 is seemed to be inconsistent with Article 11(1) and 17 of the constitution, Article 26 of ICCPR 1966, Article 2 and 3 of ICESCR-1966 and Article, 1, 2, 3 and 15 of CEDAW-1979. It is seemed to be adverse effect for continuing of this impugned provision to preserve the gender justice. So it is declared ultra-vires the section 2 of women's exclusive property in accordance with Article 1 and 88(1) of the constitution onward the date of today. In fact, the function of issuing directive order is not itself the completion of providing justice. Therefore, the exercise of power for testing constitutionality of impugned legal 


\section{ELIMINATION OF GENDER DISCRIMINATORY...}

provision may bring positive outcome for those victims who are often deceived from the language of justice.

Likewise in Meera Dhungana (11) Vs HMG/Office of Prime Minister and Council of Ministers, petitioner has challenged the section 12(a) of the chapter on intestate property of National Code 2020 in which it has been claimed to be inconsistent with the Article 11 of the Constitution of Kingdom of Nepal, 1990 and the spirit of all International Human Rights instrument including Article 1 of CEDAW convention 1979. Nepal has ratified these international instruments without any reservation in 1991. By virtue of ratification and incorporation of Nepal Treaty Act, 1990 the section 12(a) of this chapter of Intestate Property is against the norms of section 9(1) of Nepal Treaty Act, 1990. So in this case the petitioner has asked before the Supreme Court to declare ultra-vires this impugned section 12(a) as per the Article 88(1) of the Constitution of Kingdom of Nepal, 1990.

The court in this case has displayed the positive responses on the mission of elimination of gender discriminatory laws challenged by public interest lawyer. The court substantiates as absolute right the intestate property in which the successor is entitled to freely enjoy without any interference. The court states: the intestate property is the absolute property of the successor that can not be shared with other coparceners under section 18 of the chapter on partition share of National Code, 2020, one who acquires such property, is ensured to enjoy freely without any interference. So this impugned provision is inconsistent with Article 11 of the constitution as well as the norms and spirit of human rights convention. The court further opined: the married daughters or sisters have no obligation to return this kind of property only due to the cause of marital status. So, it is discriminatory not only between son and daughter but also daughter and daughter. Ultimately the court has declared null and void the impugned section 12(A) of chapter on Intestate Property of National Code, 2020. Indeed, the court has played a significant role for eliminating discriminatory legal provision and that seemed to be conducive for the maintenance of gender justice in society.

Recently, in Merra Dhungana (III) Vs Office of the Prime Minister and Council of Minister the petitioner has challenged the section 7 of the Chapter on Women's Exclusive property of National Code, 2020, which said to be inconsistent with Article 11 of the Constitution of Kingdom of Nepal, 1990, Article 2, 3, 6, 7 and 18 of UDHR-1948; Article 1, 2, 3, 4, 23 and 26 of ICCPR1966; Article 1, 2, 3 and 5 of ICESCR-1966 and Article 1, 15 and 16 of CEDAW- 1979. So the petitioner has requested before the Supreme Court to declare void and ultra-vires the impugned legal provision under Article 88(1) of the Constitution of Kingdom of Nepal.

In this case the court has demonstrated the positive response as regards the issue of elimination of discriminatory legal provisions concerning the equal property right of women. The court, in this case signifies the defect of impugned section 7 as seen as a double standard on women's property. The court further clarifies that this section provides a kind of property right in lieu of restrict of other rights. In other words, to court, this section 7 also perpetuates the changing attitude of property right if her sexual and marital status is seen to be changed. 
Ultimately, the court prudently declared void and ultra-vires of this gender discriminatory legal provision of section 7 of women's exclusive property under Article 88(1) of the Constitution of Kingdom of Nepal, 1990. Thus, in this case, the court played an important role for elimination of discriminatory law regarding women property right.

\section{CONCLUDING REMARKS}

Actually it is an undeniable fact that after the people's movementII/2062/63 the Interim Constitution of Nepal, 2063 and G.E. Act, 2063 have mostly eliminated the various gender discriminatory laws, but this study focuses the judicial approach regarding the elimination of gender discriminatory laws from the period of Constitution of Kingdom of Nepal. And it is centered upon the situation before the advent of Interim Constitution of Nepal, 2063.

Basically, the movement of property rights of women was more focused since Meera Dhungana (1) (2052) case of the Supreme Court that had heralded the genesis of the debate of women's ancestral property right issue. So far the concept of women's property right is concerned, either thinkers of western or eastern society, are not seemed to be positive in respect of women's right to property on equal footing of men's right. In Nepal, essentially, sister organizations of political parties and human rights activities of NGOs and INGOs have been playing significant role for campaigning the issue of women's equal property right. In this mission, governmental initiatives are seen to be positive for enhancing women's right to equal property. From $6^{\text {th }}$ National Plan to today's 3 year's Interim Plan, 2064, all have emphasized to eliminate existing gender discriminatory legal provisions including women's equal property right in order to advancement of empowerment of women. Additionally, after the restoration of multi party democratic system, the Government of Nepal has been ratifying various international instrument of human rights convention. In this connection Nepal has enacted the Nepal Treaty Act, 1990 that prefers under section 9(1) to the international human rights provisions if there is contradiction with the provision of domestic laws.

So far as the judicial initiative regarding the elimination of discriminatory legal provision is concerned, there seems two kinds of approach of Supreme Court in this regard. Firstly, before the stage of $11^{\text {th }}$ amendment of National Code, in this stage the court is not seemed to be positive regarding the elimination of discriminatory legal provision. For example in Meera Dhungana (1) (2052) case. Sapana Pradhan case, Chanda Bajracharya case the court has displayed unwillingness for declaring null and void/ ultra-vires the discriminatory legal provisions. Rather the court seemed to be escaped through issuing directive order in the name of government for introducing appropriate bill before the parliament. It seemed that the court intended to maintain patriarchal hegemony in legal systems.

Secondly, after the $11^{\text {th }}$ amendment of National Code the court has changed its stance and it looked more positive. For example, Prakashmani Sharma case, Lily Thapa's case, Meera Dhungana (11) and (111) case, the court has conceded the demand of petitioners for declaring ultra-vires the 
discriminatory legal provisions regarding women's property right. Hence, the court seems to be successful to catch the demand of time.

\section{WORKS CITED}

भार्या पुत्रश्च दासश्च त्रय एवाधनाः स्मृताः । यत्ते समधी गच्छन्ति यस्य ते तस्य तद्धनम् ॥ T. Luitel. 2061. Manusmriti. Kathmandu: Pairavi Prakashan. English Version translated by W. Doniger and B.K. Smith (1991). The Law of Manu. Delhi: Penguin Book India Ltd.

न निर्हारं स्त्रिय: कुर्यु: कटुम्बाद्ध हु मध्य गात् । स्वकादपि च वित्ताद्धि स्वस्थ मर्तुरना ज्ञा ॥ Id. T. Ouitel page 232. See Also Id. W. Doniger and B.K. Smith.

स्वे भ्योऽशेभ्यस्तु कन्याभ्यः प्रदद्युभ्रातर पृथक । स्वात्स्वादंशा च्चतुमार्ग पतिता स्यूर दित्सव: ॥ Id. T. Lutiel at 223 and Ide. Doniger and Smith.

इकोवात्मा थैवारमा तथा पुत्रेण दुहिता सभा । तस्यामात्मनि तिष्ठन्त्यां कथ मन्यो धनम् हरेत् । Id. Luital at 224 and Id. Doniger and Smith at 213.

Article 1 of CEDAW Convention - 1979.

Article 1(1) of the Constitution.

Article 15 (1) of CEDAW Convention - 1979.

Article 15 (2) of CEDAW Convention - 1979.

Article 16 (1) (h) of CEDAW Convention- 1979.

Article 17 of UDHR - 1948 UN.

Article 23 of the Constitution of Kingdom of Nepal, 1990.

Article 3 of International Covenant of Economic, Social and Cultural Rights1966. UN GA. Resolution No. 2200A (XXI) of 16 Dec., 1966.

Article 88 (1) of the Constitution of Kingdom of Nepal.

Article 88(1) of the Constitution of Kingdom of Nepal, 1990.

Blackstone's Commentaries. 1808. Cited from W.W. Williams (1991). "The Equality Crisis: Some Reflection on Culture, Courts and Feminism" in K. T. Bartlett and R. Kenanedy (eds.), Feminist Legal Theory Reading in Law and Gender, USA: Westview Press, p. 16.

CEDAW was adopted by UN General Assembly Resolution, 34th Sess. Supp. No. 21 at 193. UN Doc A/Res/34/180 (Entered into Force Sept. 3, 1981).

Deuja, J. 2005. "Bhumima Mahila Adihikar" (in Nepali). Kantipur, Dec. 7, p. 7.

Engel, F. 1884. The Origin of the Family Private Property and the State. (In Nepali, 1999), Kathmandu: Pragati Prakashan Translated by R. Maskay.

Freeman, M.A. 1994. "Women, Law and Land at the Local Level: Claiming Women's Human Rights in Domestic Legal System." Human Rights Quarterly, Vol. 16, No, 3, Aug., p. 571.

FWLD. 2006). Discriminatory Laws in Nepal and their Impact on Women. Kathmandu: Forum for Women Law and Development. 
General Assembly Resolution 217A (111) UN DOC. A/810 (1948).

General Assembly Resolution 2200 (XXI) UN Doc. A/6316 (1966).

HMG/MWCSW. 2004. National Plan of Action for Implementing the Convention on the Elimination of all Forms of Discrimination Against Women (CEDAW). Kathmandu: His Majesty's Government Ministry of Women, Child and Social Welfare

HMG/MWCSW. 2004. National Plan of Action on Gender Equality and Women Empowerment, 2004. Kathmandu: His Majesty's Government, Ministry of Women Children and Social Welfare

Kandel, D.P. 2005. Property Rights of Women in Nepal. Kathmandu: Ratna Pustak Bhandar

Kuba, S.K. 1986. Status of Women in International Law. New Delhi: Delhi Law Book Co.

Meera Dhungana and other Vs HMG/Ministry of Law, Justice and Parliamentary Affairs, NKP 2052 (1995), Vol. 5, p. 462.

Nepal had ratified both ICCPR-1966 and ICESCR-1966, in 19 May 1991 and CEEDAW Convention-1979 was ratified in 22 April, 1991.

Nepal Treaty Act, 1990.

NKP 2052 (1995 A.D.) Writ No. 8392 of the year of 2050.

NKP 2053 (1996), Vol. 38, p. 105.

NKP 2053 (1996), Vol. 7, p. 537.

NKP 2061, Vol. 4, Writ No. 7357.

NKP 2062, Decision No. 7588, p. 1054.

NKP 2063 Dec, No. 7577, p. 931.

NKP 2063, Vol. 48, Dec. No. 7743, p. 979.

NPC. 1980/81-1984/85. Sixth Plan, Kathmandu: HMG/National Planning Commission Nepa, p. 725.

NPC. 1992-1997. $8^{\text {th }}$ Plan. Kathmandu: HMG/National Planning Commission Nepal, pp. 710-713.

NPC. 1997-200). 9 $^{\text {th }}$ Plan. Kathmandu: HMG/National Planning Commission Nepal, p. 146

NPC. 2002-2007. Tenth Plan. Kathmandu: HMG/National Planning Commission Nepal. p. 524.

NPC. 2007 Dec. 2064 B.S.. Three Years Interim Plan. Kathmandu: Nepal Government, National Planning Commission, Nepal, pp. 96-106.

Osho, R. 2001. Nari Aur Kranti. Delhi: Diamond Pocket Book.

Rig- Veda 9-112-3.

Rig-Veda 10-85-7. 


\section{ELIMINATION OF GENDER DISCRIMINATORY...}

Rig-Veda 1-109-2 Cited from A. Kanta. 2003. Women and the Law. New Delhi: APH Publishing Co.

Rig-Veda 2-17-7.

Sangrauala, Y. \& P, Gita. 2002. Gender and Laws: Nepalese Perspective, Kathmandu: Pairavi Prakahan

Section 1 of Chapter on Partition Share of National Code, 2020.

Section 1 of the Chapter on Intestate Property of National Code, 2020.

Section 1 of the Chapter on partition Share of National Code, 2020

Section 16 of the Chapter on Partition Share of National Code, 2020.

Section 16 of the same chapter.

Section 2 of chapter on women's exclusive property (Stri Amsa Dhan).

Section 2 of Women's Exclusive property chapter of National Code, 2020.

Section 7 of the same chapter states.

Section 7 of Women's exclusive property chapter of National Code, 2020.

Sivaramayya, B. (1973). "Women's Rights of Inheritance in India" in The Madras Law Journal, Madrsaa, P. 125.

Thapalia, S. 2050. "Nariko Arhik Vipannata Nai Hindu Sastrakio Nirdeshan ho ta." (in Nepali) LACCLENS. Vol. 8, p. 21.

The CEDAW Committee's Concluding Observations/Comments over the Initial Report of Nepal. 1999 Para 138. The Initial Report was presented by the representative of Nepal before CEDAW Committee at its $434^{\text {th }}$ and $439^{\text {th }}$ meeting, on 15 and 18 June, 1999.

Krishna Iyer, V.R. 1983. "Human right to be Human" in Kusum (ed.) Women March Towards Dignity: Socio-Legal Perspective, Delhi: Regency Publication, pp. 1-22. 